\title{
A PRESENT-DAY PHASE OF MISSIONARY THEOLOGY
}

\author{
'I CAME NOT TO DESTROY BUT TO FULFIL'
}

THIs article is not concerned with the teachings or writings of any individual; its purpose is to deal with a mental attitude which has scarcely passed beyond that stage into the region of definite conclusion.

The replies to questions sent out to the mission field by commissioners appointed to prepare material for the Edinburgh World Missionary Conference appeared to suggest that missionary experience had now shown that a new attitude towards the ethnic religions was demanded. Individual utterances in the mission field have also seemed to point in the same direction, and to suggest that the message of Christianity to the nations as presented by the pioneers of the missionary enterprise must be replaced by a new method of approach, of which a deeper sympathy with the religions of these nations and a higher appreciation of their spiritual content shall be the distinguishing features.

The characteristic note of this method is held to be expressed in the words of our Lord Himself which I have placed at the head of this article-' I came not to destroy but to fulfil.' 'This may be called the motto of the school and, as interpreted by the more extreme representatives of this missionary position, it means that the function of Christianity in relation to the ethnic faiths is not to supplant these systems by a new faith but to supplement them, to 'fulfil' them by furnishing the complement and consummation that is contained in the Christian gospel. As the gospel of Christ brought to the religion of the Old 
Testament its fulfilment, absorbing the old and reproducing it in its complete development, so it must ever be the mission of Christianity to absorb, vivify and raise to complete achievement the religious thought of all the nations and of all the ages. The religions of India, and especially Hinduism, are the examples that are adduced in illustration of this process, and the philosophies that underlie the popular religions of India, especially the Vedanta in one or other of its forms, are held to furnish a foundation on which Christianity may rear the fabric of a higher religious life and bring to fulfilment the thought and aspiration of India's past. It has even been seriously contended that in some respects these systems supply a more satisfactory foundation than the Old Testament, and that the Indian Church might with distinct spiritual advantage introduce into its religious worship readings from the Upanișhads and Vedanta as a portion of its Old Testament lessons. Not many, we venture to think, of the representatives of this phase of missionary thinking would be prepared to endorse this proposal; but the fact that it has been publicly brought forward shows that it is time that the whole process by which this result has been reached should be subjected to serious examination.

The problem which meets the Church to-day in its contact with ancient systems of religious thought is not a new problem. It had to be faced by the early Christian Church as soon as the missionary impulse had led its apostles and first missionaries into the presence of nations that could look back upon long eras of philosophic and literary culture as part of their national inheritance. The apostle Paul was one of the first who had to face the problem, and from the summary of his address to the people of Athens that is given in the Acts of the Apostles, and from several of his epistles to the Churches, we learn with some degree of exactness how he dealt with it. His loving heart, sensitive to - ery movement of thought amongst thcse to whom he brought his message, kept him on the alert to 
meet every disposition of mind that seemed likely to provide a channel for the entrance of the gospel which he proclaimed. In the Athenian capital, filled with temples and images, he found a witness to the reality and persistence of man's search for God. With tender touch he exposes the fundamental errors of idolatry, and when he points to the recognition of failure which he reads in the inscription 'To the Unknown God' he describes the search which has ended in this failure as noble, and as included in the wide purpose of God towards the nations of men whom $\mathrm{He}$ has made in His own image. In his epistles he expands the same thought, setting forth the failure of the wisdom of men as a preparation for the message of the wisdom and the power of God.

There was much in the philosophies of Greece that was lofty in its ethics and spiritual in its theology. This, we might have imagined, the apostle would have chosen as the starting-point of his approach to the Athenian mind; but he deliberately chooses another path. He recognizes in the strivings of the nation's thought a divine providence which gives to them a definite place in the divine purpose. He does not ask the Athenians to believe that through these ages of seeking and feeling after God they lay outside His thought and care. God was leading them even when they failed to find Him, preparing them by their search and by its failure to enter on the path along which His grace could draw near to them. In the experiences of human seeking and human failure through which they had passed the apostle finds the 'evangelical preparation' of the nations, and to 'fulfil' this Christ came. The apostle enters into no discussion of those philosophies. From the standpoint of their ethical and spiritual result there was no room left for such discussion. Their spiritual powerlessness stood revealed in the moral paralysis of the people to whose life they should have ministered.

It might be said that Paul was unfitted by the natural and national bent of his Jewish mind to appreciate the 
relation of these systems to the fundamental doctrines of the faith which he proclaimed. It may be also argued that his acquaintance with the systems of Hellenic thought was too limited to make such an appreciation possible. But it is not necessary in estimating his attitude to preChristian thought to discuss the question of the extent of the apostle's education in ancient philosophy. In all his writings he has made it clear that the only results of human thought that count in this great argument are those which are visible in man's knowledge of God in the moral aspects of His being and man's realization of himself in the moral relations which he sustains to God and to humanity. Thus judged man's wisdom has failed; by the path of intellect God, the God whom man's soul hungers and thirsts after, is not to be found.

To him Christ is the fulfiller in the sense in which the Lord Himself claimed to have come not to destroy but to fulfil. He was the fulfilment of the revelation enshrined in the history of the people of the covenant, of the law which had been given to be a ' schoolmastcr' to lead to Him, of the religious development which had been in process throughout the long and many-coloured history of the people of God. St. Paul's conception of Jesus as fulfiller is related to this well-defined region, and only a forced and unnatural interpretation can find in the memorable saying of our Lord a wider application. Interpret the word 'fulfil' in a vague sense which detaches it from the context of our Lord's great sermon and you can find in it a reference to every thought and experience of mankind. There is a sense in which Christ is the fulfiller of all things. St. Paul's Christology is comprehensive enough to include this universal significance also; but, in the specific sense which the phrase is intended to bear in the argument now under consideration, the idea of Christ as the fulfiller does not appear in the sayings of our Lord or His apustles with reference to the general course of human thinling on the things of God. 
The thought which underlies the position we are discussing appears to emerge with some measure of definiteness in the writings of Clement of Alexandria. These writings possess a peculiar interest as exhibiting the first real attempt to place the teachings of the Christian faith in a definite relation to those of the ancient philosophies. Clement was himself well versed in the teachings of the ancient schools. His acceptance of Christianity came at the end of a long course of study of these systems, and when he emerged from his search into the light of Christ he found in Him the fulfilment of his intellectual and spiritual desires. As he looks back along the paths by which his seeking soul has wandered, he sees them in the reflected light that comes from the divine Logos that was manifested in Jesus Christ. To him the truths contained in these philosophies are so many scattered rays of divine light which have all been gathered up in Christ, the Sun of Righteousness, the brightness of the Father's glory. As a theological statement the view of Clement was never seriously regarded by the ancient Church. It probably did not mean much more than the anima naturaliter christiana of Tertullian; but, in the view of some, it served probably along with other things to delay the canonization of this distinguished church father. His position is one with which Christians of all the ages ought to have no difficulty in finding themselves in fullest accord. In the ancient literature to which he refers there are gleams of truth which the Christian Church ought to be ready to accept as an evidence of the diffused energy of the divine Logos in the world, and the same may be said with equal conviction regarding the thoughts which sustained the philosophies of India through ages of profound spiritual sceking after God.

No Christian missionary who has been able to get near to the underlying thought of India's religious literature can fail to be touched to sympathy and appreciation. The pioneers of missionary enterprise were no exception 
to this experience. Many of them were profound students of the religious literature of India, and their love for India's people was deepened by everything truly spiritual that their studies disclosed to them. We are all willing and glad to recognize the operations of the divine Logos in every spiritual truth that has been revealed to the seeking heart of India. But this sympathy and this recognition need not blind us to essential distinctions. The systems of religion with which we find ourselves confronted are not the true counterpart of those higher thoughts which disclose themselves to the sympathetic student of India's literature. They stand before us the evidences of the pathetic failure of India's highest thinking to achieve for the people of India the satisfaction of their religious needs. They have grown out of systems of thought that were inspired by high desire; but, while they find their support in the philosophies which arose in answer to this desire, they have not been true to their loftier origin. It is impossible, therefore, to regard them as steps in a development that finds its culmination in the religion of Jesus Christ. In the sense in which the religion of the New Testament is the fulfilment of that of the Old, Christianity cannot be presented as the fulfilment of Hinduism or any ethnic faith. It is not unusual to find in the sayings of Jesus, even in those which seem particular and casual, a universal significance that extends far beyond their first application; but it can with little show of reason be maintained that when Jesus in the course of a minute and detailed illustration of the Mosaic law describes Himself as come not to destroy but to fulfil, $\mathrm{He}$ is placing Himself in the same relation to all other systems of human thought and religious practice. His statement is precise and definite, and in making it $\mathrm{He}$ claims to be a fulfiller of the law in a sense in which $\mathrm{He}$ is the fulfiller of nothing else.

This generalizing of the words of Jesus has been used in the defence of some very extreme positions. A remarkable example of this is found in a recently published work 
on Hinduism which appears under the title The Crown of Hinduism. The exposition of Hinduism contained in this work is both thorough and illuminating, while its analysis of the teachings and practices of Hinduism, and its exposure of the errors of the one and the evils of the other are uncompromising and complete. The only feature of the work that jars on one's sense of fitness is the title, for the Crown of Hinduism means Christianity. The introduction and a few passages in the book are devoted to the exposition of the idea which underlies the title. The title means to convey the idea that Christianity is the consummation, the fulfilment of Hinduism. In a few of the chapters which deal with the more general problems of religion, in relation to which the underlying thesis can be maintained with some appearance of propriety, the proposition is reasserted, and at the end of the work it reappears in a sentence. But throughout the body of the work, where the writer is grappling with the real problemthe life, the spirit and the practice of concrete Hinduismthe formula is allowed to fall into the background, for the author cannot but shrink from the assertion that Christ is the fulfilment of that which he has exposed as conflicting with the true conception of the divine character and with the ethical demands of the human spirit.

There must be many who, while they appreciate the contents and the purpose of the work, regret that it is marred by a title which is really irrelevant to its subject and in contradiction with its main positions. A writer on the religious movements of Hellenism might with much greater appearance of fitness describe Christianity as the Crown of Hellenism, and it must be asserted in all seriousness that, if one could accept the position of the writer who finds in sati and in the dedication of young girls to a life of immorality by marrying them to a god something that points to a higher devotion and prepares the way for it, there is no human thought or human practice for which Christianity might not be claimed as its crown. 
We have referred to this work not for the purpose of a criticism of its positions but in order to illustrate the attitude towards non-Christian faiths that is at present under discussion. We refuse to call Christianity the Crown of Hinduism in the sense in which this writer expounds the title of his book and we decline to share the attitude of which it may be taken as a typical illustration. We refuse to accept this method of approach for our message to the mind of India, because it is calculated to misrepresent the one and to mislead the other.

We hold very strongly that we are misleading India when we present to it the Christian gospel as the consummation of its own distinctive religious development. Such a message brings no spiritual help to India; it only tends to confirm India in a mistaken estimate of its own spiritual achievement, and to neutralize the effect of the preparatio evangelica through which India has been called to pass in the expcrience of its own religious history.

Every missionary in India knows that the most formidable barrier that Christianity encounters in its approach to the higher mind of India is this belief in the greatness of the spiritual achievements of India's past. Such minds dwell on what they call the materialism of the West and contrast it with the spirituality of the East which they claim as their inheritance, and they regard as presumptuous the suggestion that they should be cxpected to listen to a spiritual message coming to them through any western channel. And, until India has learned the true meaning of spirituality and has come to acknowledge the lack of it in much that bears this high name, this attitude of the Indian mind will prove a formidable obstacle to Christian progress. India has yet to lcarn that a spirituality which is reached by the path of abstract metaphysical speculation is a very different product from a spirituality which is essentially cthical in its origin and in its manifestation. It is the mission of Christianity to lead it into the path which Jesus Christ has opened up to the world in His life, in His 
teaching, and in His sacrifice for men. The message of Christ is the revelation of a new spirituality, not merely the consummation of the spirituality on which India has striven to nourish its life. It is the duty of every Christian to recognize the grandeur of India's effort, the grandest in the history of human thought; but it is none the less the duty of every missionary who loves India and seeks to help India to point out wherein its highest efforts have failed to reach the true goal of the spiritual life as revealed by Jesus Christ. The mission of Christianity is not to complete or consunımate something that has been moving onwards to this completion; but to reveal to India a new way and a new power.

From much that has been written in connexion with the advocacy of a new method of reaching the mind of India, it would appear that it is put forward by its advocates as calculated to accelerate the rate of Christian progress in India. Impatient of the slow movements of the kingdom of God, these earnest spirits have rushed to the conclusion that the slowness of these movements has been due to a mistaken method of presenting the Christian message, and the use of strategical methods that were illconsidered and ineffective. All such impatience is to be encouraged, for we are only too apt to satisfy ourselves with meagre achievement in this high service; but the conclusion that a new conception of the function and the mission of Christianity will change all this has little warrant in the history of the past or in the indications which meet us in the present. We have no sympathy with the methods of those who are censured by this new school of missionary thought as delighting in denunciations of Hindu superstition and in ruthlessly assailing the cherished beliefs of a religious people. We doubt whether such methods have ever had a place in the practice of any reputable missionary in the past, nor are we aware that they are followed by any missionaries of experience in the present. Such methods are alien to the whol: spirit of our Christian faith, 
and involve a complete departure from the type of apostolic preaching that stands forth in the New Testament record. Such a method of approaching the mind of India is an outrage on the religious sense of humanity and must ever prove fatal to its own purpose. But, while we repudiate in terms as strong as any employed by some modern missionaries this attitude of aggressive hostility, we are persuaded that there are dangers quite as great in the extreme position which these missionaries have been led to advocate.

I can understand the thoughtful Hindu who has been told that Christianity is the consummation of his religion, the high goal towards which it has been moving through ages of spiritual evolution, taking refuge in the position that if his religion has thus developed in the past he is content to allow the process to work out its own consummation, and that there is no reason why he should be invited to accept the highest stages through the new channel which Christianity offers to him.

This is not a merely imaginary attitude; it is the actual attitude of many of the religiously minded amongst the thoughtful classes in India. They feel that they have behind them a great religious history, and they are looking forward to future developments rooted in that ancient past which will be independent of all extraneous contributions including those which have their definite origin in the Christian faith. This conviction, definitely formulated or existing only as an undefined feeling, explains in large measure the reluctance of many of the more enlightened class to entertain seriously the overtures of the Christian religion. Even when Christian ideals lay hold on their imagination they are reluctant to attribute them to Christianity and are disposed to claim them as the genuine fruits of their own religion when rightly interpreted.

It was not so in the days of the earlier religious movements which were awakened in India by the advent of Christian missionaries. The first great reformers of this 
period were not slow to acknowledge their obligations to Christ and His religion, and some of the most eloquent human tributes to Jesus Christ were penned by the Hindu religious reformers of last century. To-day we have to reckon with a new attitude. The spirit of nationalism has been awakened and is asserting itself in every field of Indian life and not least in that of religion. This new life to the awakening of which Christian influences have so largely contributed has evoked a spirit of intense nationalism in regard to religion. The acceptance of the Christian faith is viewed not simply as an act of religious apostasy; it has come to be regarded in many quarters as treason against the national spirit. No missionary who is in contact with the thinking classes of India can fail to recognize that this, and not the purely religious influences of Hinduism, is the strongest force with which his message has to reckon. Does any one imagine that to present Christianity as the consummation of Hinduism will have any conciliating influence on minds that are saturated with the new spirit? Is it not rather our mission to India to present to it a Christ who is not the consummation of any nation's strivings but the answer of the divine grace to the needs of mankind? The more we exalt the Christ as a God-given Redeemer who comes to man in the hour of his helplessness and failure, the more effectively shall we discharge our mission to the peoples of India. Let us recognize the nobility of India's religious strivings- to us the noblest and the grandest spectacle in all its history-let us put the best interpretation on all that India has achieved in the domain of religious thought, but let us not conceal from India that its religious history, like that of other nations, has failed to lead it to the true knowledge of God. The dark shadow of failure lies across that history-a failure common to India with all the nations of mankind, but more pathetic than all other failures by reason of the lofty heights to which Hindu thought has risen in its search after God and the passionate faith with which 
India has clung to the Unknown whom its thinking could not reveal. In such an attitude there is no lack of true spiritual sympathy with the ethnic religions of the world; there is only a humble recognition of the truth, taught by apostles and confirmed by the world-wide experience of the Church of Christ, that when ' in the wisdom of God the world by wisdom knew not God it pleased God by the foolishness of preaching to save them that believe.'

D. Mackichan 